\title{
CRM1 inhibitory and antiproliferative activities of novel 4'-alkyl substituted klavuzon derivatives
}

\author{
Tuğçe Kanbur ${ }^{\mathrm{a}}$, Murat Kara ${ }^{\mathrm{a}}$, Meltem Kutluer ${ }^{\mathrm{b}}$, Ayhan Şen ${ }^{\mathrm{c}}$, Murat Delman $^{\mathrm{b}}$, Aylin Alkan ${ }^{\mathrm{c}}$, \\ Hasan Ozan Otaş ${ }^{c}$, İsmail Akçok ${ }^{\mathrm{a}}$, Ali Çağır ${ }^{\mathrm{a}, *}$ \\ a İzmir Institute of Technology, Faculty of Science, Department of Chemistry, Urla 35430, Izmir, Turkey \\ ${ }^{\mathrm{b}}$ Izmir Institute of Technology, Biotechnology and Bioengineering Graduate Program, Urla 35430, Izmir, Turkey \\ ' Izmir Institute of Technology, Faculty of Science, Department of Molecular Biology and Genetics, Urla 35430, Izmir, Turkey
}

\section{A R T I C L E I N F O}

\section{Article history:}

Received 13 May 2017

Revised 10 June 2017

Accepted 16 June 2017

Available online 19 June 2017

\section{Keywords:}

Klavuzon

Anti-proliferative activity

CRM1 inhibition

Pancreatic cancer

Hepatocellular carcinoma

3D cell culture

\begin{abstract}
A B S T R A C T
Klavuzons are 6-(naphthalen-1-yl) substituted 5,6-dihydro-2H-pyran-2-one derivatives showing promising antiproliferative activities in variety of cancer cell lines. In this work, racemic syntheses of nine novel 4 -alkyl substituted klavuzon derivatives were completed in eight steps and anticancer properties of these compounds were evaluated. It is found that size of the substituent has dramatic effect over the potency and selectivity of the cytotoxic activity in cancerous and healthy pancreatic cell lines. The size of the substituent can also effect the CRM1 inhibitory properties of klavuzon derivatives. Strong cytotoxic activity and CRM1 inhibition can be observed only when a small substituent present at 4'-position of naphthalen-1-yl group. However, these substituents makes the molecule more cytotoxic in healthy pancreatic cells rather than cancerous pancreatic cells. Among the tested compounds 1,2,3,4-tetrahydrophenanthren-9-yl substituted lactone was the most cytotoxic compound and its antiproliferative activity was also tested in 3D spheroids generated from HuH-7 cell lines.
\end{abstract}

(c) 2017 Elsevier Ltd. All rights reserved.

\section{Introduction}

Current the 5-year survival rates for lung and pancreatic cancers are $18 \%$ and $8 \%$, respectively. These low survival rates are partially because of the late diagnosis of one-half of cases, in which 5year survival decrease to $4 \%$ and $3 \%$, respectively. ${ }^{1}$ Currently, FDA has approved more than ten anticancer drugs for the treatment of pancreatic cancer but poor survival rates indicates the urgency of the development of novel anticancer drug candidates. In this work, development of novel klavuzon derivatives, as new anticancer drug candidates for the treatment of pancreatic cancer, was studied.

In recent years, there is an increase in the number of studies for the discovery of drug candidates, which act by covalent binding to the nucleophilic sites of the macromolecules inside the cells. Almost, $30 \%$ of drugs in use today act as covalent inhibitor. ${ }^{2}$ One of the most common motif in the structure of natural products is $\alpha, \beta$-unsaturated- $\delta$-lactone that can act as an irreversible inhibitor through a covalent bond formation. It is believed that, nucleophilic

\footnotetext{
* Corresponding author.

E-mail address: alicagir@iyte.edu.tr (A. Çağır).
}

site of the enzymes can bind to the $\beta$-carbon of the lactone pharmacophore through by Michael addition. ${ }^{3}$

$(R)$-Goniothalamin (1) is one of these natural products and was isolated first in 1967 by Hlubucek from Cryptocarya caloneura. ${ }^{4}$ Its selective cytotoxic activity against cancer cell lines ${ }^{5,6}$ draw the attention of scientist and many research groups have put effort in synthesizing novel derivatives of goniothalamin to understand the structure activity relationship. ${ }^{7-16}$ On the other hand, a few number of studies were dedicated to explore the mechanism of action of goniothalamin derivatives such as inhibition of CRM1 nucleocytoplasmic transport receptor protein ${ }^{17}$ and inhibition of topoisomerase $\mathrm{I}^{18}$ In terms of cell death, it was shown that $(R)$ enantiomer of goniothalamin induces apoptosis while $(S)$-enantiomer induces autophagy. ${ }^{19}$ Efficiency of racemic and enantiomerically pure forms of goniothalamin was also demonstrated in Ehrlich solid tumor in mice. ${ }^{20}$

Previously, synthesis and antiproliferative activity of conformationally constrained $(R)$-goniothalamin $((\boldsymbol{R})-\mathbf{2})$ was reported by our group. Although it was found that antiproliferative activity of compound $(\boldsymbol{R})-\mathbf{2}$ was higher than that of $(R)$-goniothalamin (1), naphthalen-1-yl substitution at position-6 of 5,6-dihydro- $2 H$-pyran-2one pharmacophore further increases the activity. The inventors named this compound as "klavuzon". In the same study, $(R)-4$ '- 
<smiles>O=C1C=CC[C@H](/C=C/c2ccccc2)O1</smiles>

(R)-1

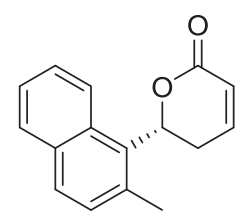

(R)-4

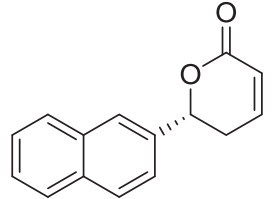

(R)-2

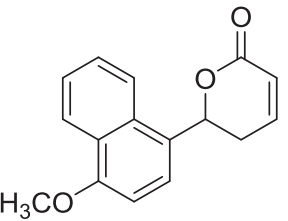

5

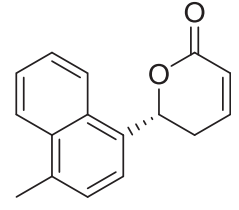

(R)-3

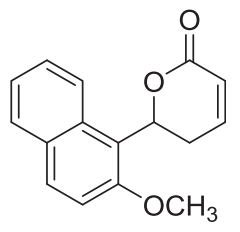

6
Fig. 1. Structures of $(R)$-goniothalamin (1), conformationally constrained $(R)$ goniothalamin (2), 4'- and 2'-substituted klavuzon derivatives (3-6).

methylklavuzon $((\boldsymbol{R})-\mathbf{3})$ and $(R)-2^{\prime}$-methylklavuzon $((\boldsymbol{R})-\mathbf{4})$ were found to be the most cytotoxic compound. ${ }^{21}$ In a recent study, racemic 4 '-methoxyklavuzon (5) and (R)-2'-methoxyklavuzon (6) derivatives were also prepared and they were found to be less cytotoxic compared to their methyl counterparts $((\boldsymbol{R})-\mathbf{3}$ and $(\boldsymbol{R})-$ 4). In the same study, topoisomerase I inhibitory property of klavuzon derivatives was also represented (Fig. 1). ${ }^{18}$

Multi-target drug discovery gained significant attention in the last decade to overcome the difficulty of curing diseases having complex etiology and drug-resistance issues. ${ }^{22}$ In this respect, goniothalamin derivatives can be considered as a dual acting inhibitor because of its capability to inhibit both CRM1 and topoisomerase I. Due to their structural similarity to goniothalamin, klavuzons may also have similar dual acting inhibitor property. Previously, topo I inhibitory property of klavuzons was shown. In this study, synthesis and antiproliferative properties of novel 4'alkyl substituted klavuzon derivatives in pancreatic cancer cells (MIA PaCa-2) and Human pancreatic ductal epithelial cells (HPDEC) will be presented. Their time and concentration dependent CRM1 inhibitory properties will also be discussed.

\section{Results and discussion}

Racemic syntheses of $4^{\prime}$-alkylklavuzon derivatives (16a-h) were completed in eight steps. Strategically important ethyl 4alkyl-1-naphthoates (10a-h) were prepared according to the procedures reported in literature starting from 4-methyl-1-naphthoic acid (7) in three steps. As can be seen in Scheme 1, benzylic bromination of ethyl 4-methyl-1-naphthoate (8) was performed by a NBS-benzoyl peroxide mixture to produce compound $\mathbf{9}$ in $92 \%$ yield. In the next step, the copper (I)-catalyzed addition of various freshly prepared Grignard reagents to 4-bromomethyl-1-naphthoate (9) was successfully performed. ${ }^{23}$ Interestingly, varying amounts of dimerization product (11) of 4-bromomethyl-1-naphthoate (9) were also observed.

Ethyl 1-naphthoates (10a-h) were successfully reduced to 1naphthylmethanols $(\mathbf{1 2 a}-\mathbf{h})$ by using $\mathrm{LiAlH}_{4}$ with $8-87 \%$ yields. Then PCC was used to convert the alcohols into the corresponding 4-alkyl-1-naphthaldehyde derivatives (13a-h) with relatively higher yields (58-90\%) as represented in Scheme 2. Then, a wellknown three step synthesis was used to complete the syntheses. Simply, addition of allylmagnesium bromide over 1-naphthaldehydes (13a-h) and commercially available 4-methyl-1-naphthaldehyde (13i) yielded homoallylic alcohols (14a-i) in 54-91\% yields.
Acrylation with acryloyl chloride in the presence of triethylamine followed by ring closing metathesis reactions gave the final klavuzon derivatives ( $\mathbf{3}$ and $\mathbf{1 6 a}-\mathbf{h}$, Scheme 2). Another important klavuzon derivative $\mathbf{2 0}$ was also prepared by the same three step synthesis starting from commercially available 1,2,3,4-tetrahydrophenanthrene-9-carbaldehyde (17) as represented in Scheme 3.

Alternatively, 5,6-dihydro-2H-pyran-2-one pharmacophore can be prepared from the isomerization of 3,6-dihydro-2H-pyran 2-one in the presence of an amine base. A similar isomerization can also be observed for naphthalen-1-yl substituted 3,6-dihydro-2H-pyran 2-one derivatives inside the cells to give the corresponding klavuzons, so derivatives of 3,6-dihydro- $2 \mathrm{H}$-pyran 2-one may have therapeutic importance. For these reasons, a list of 4-alkylnaphthalen1-yl substituted 3,6-dihydro-2H-pyran 2-one derivatives (23a-e) were also prepared starting from 4-methyl-1-naphthoic acid (Scheme 4).

Compounds 13a-h were synthesized by the same synthetic route reported above and then reacted with vinylmagnesium bromide to give allylic alcohols 21a-e with $67-87 \%$ yields. Steglich esterification of the formed alcohols with but-3-enoic acid gave esters 22a-e. Finally, ring closing metathesis reactions of the esters 22a-e yielded 4-alkylnaphthalen-1-yl substituted 3,6-dihydro- $2 \mathrm{H}$ pyran 2-one derivatives (23a-e).

Although, compounds 23a-e were isolated and characterized successfully, it was noted that these compounds totally decomposed even at $+4{ }^{\circ} \mathrm{C}$ in three months. Decomposition of 6-(4methylnaphthalen-1-yl)-3,6-dihydro-2H-pyran 2-one (23a). was also shown by ${ }^{1} \mathrm{H}$ NMR spectroscopy in Fig. 2. Observed instability of the 4-alkylnaphthalen-1-yl substituted 3,6-dihydro-2H-pyran 2one derivatives led us to convert compound $\mathbf{2 3 b}$-e to the corresponding klavuzon derivatives $\mathbf{1 6 b}-\mathbf{e}$ by isomerization with DBU, instead of testing them to determine their antiproliferative properties (Fig. 3).

Antiproliferative properties of all prepared klavuzon derivatives $(\mathbf{3}, \mathbf{1 6} \mathbf{a}-\mathbf{h}$ and 20) were tested in healthy (HPDEC) and cancerous (MIA PaCa-2) pancreatic cell lines by MTT cell viability assay. Camptothecin (CPT) was used as positive control. There were differences between the cell culture conditions of both cell lines, and the most important difference was that HPDEC should be cultured (and tested) over type I collagen coated surface. Because there is a Michael acceptor in the structure of klavuzon, a small amount of the tested compounds can bind to the collagen and actual level of cytotoxicity may not be observed. To determine the effect of the collagen in MTT assay, three klavuzon derivatives $(\mathbf{3}, \mathbf{1 6 b}$ and $\mathbf{1 6 c})$ were also tested in MIA PaCa-2 cell lines which are cultured in type I collagen coated 96 well microplate. All $\mathrm{IC}_{50}$ values calculated for klavuzon derivatives were summarized in Table 1.

According to these data, collagen coating did not have any influence in structure activity relationship of klavuzon derivatives. It slightly increased the $\mathrm{IC}_{50}$ values for compounds $\mathbf{3}$ and 16c. It might be possible that MIA PaCa-2 cell viability and resistance to goniothalamin increases in the presence of type I collagen or a small amount of klavuzons was bound to the collagen as expected. On the other hand, effect of collagen over the $\mathrm{IC}_{50}$ value of compound $\mathbf{1 6 b}$ was more dramatic. It is difficult to announce the reason for this difference between the $\mathrm{IC}_{50}$ values of compounds $\mathbf{1 6 b}$ and 16c. In one thought, this difference may not be the result of interactions between klavuzon and collagen because if that is the case compounds $\mathbf{1 6 b}$ should have similar $\mathrm{IC}_{50}$ values for HPDEC and MIA PaCa-2 cell lines cultured over collagen. Only explanation can be the development of a resistance in MIA PaCa-2 cells when they grow over collagen. Overall, it can be concluded that SAR of klavuzon derivatives was not affected by collagen coating (Table 1). 

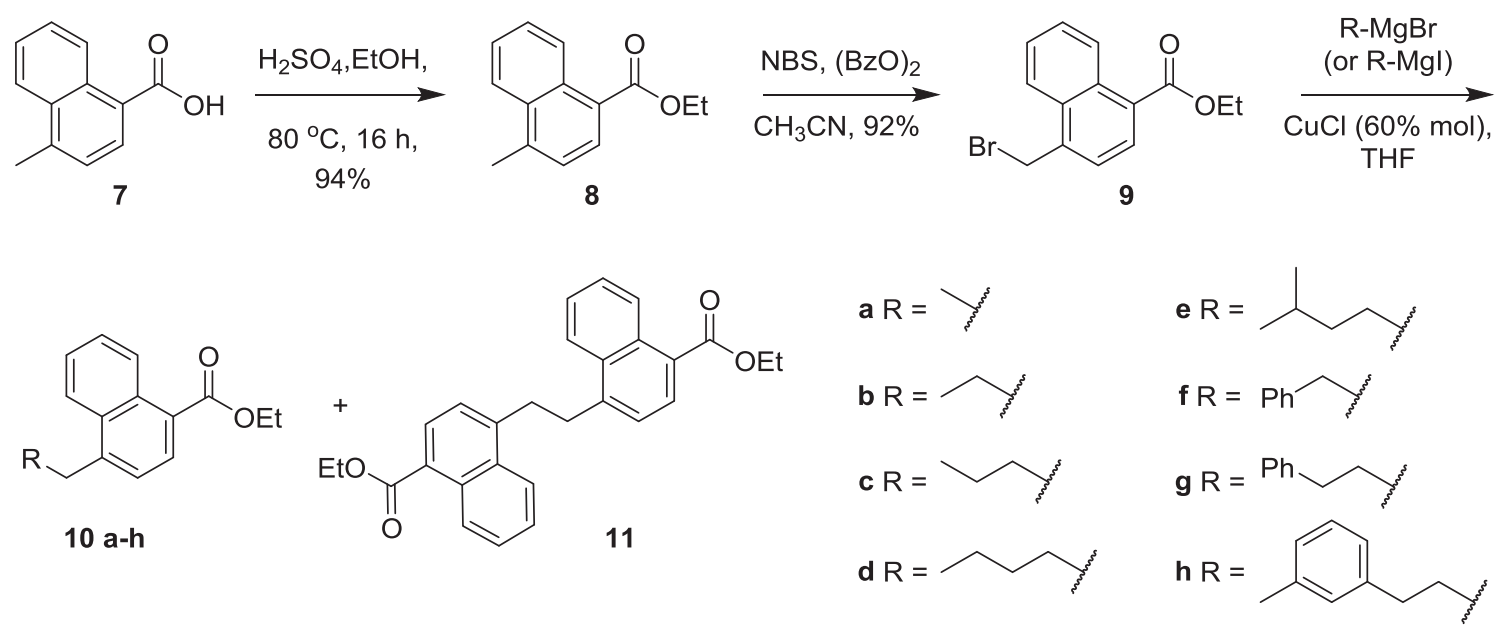

Scheme 1. Conversion of 4-methyl-1-naphthoic acid (7) into ethyl 4-alkyl-1-naphthoate derivatives (10a-h).
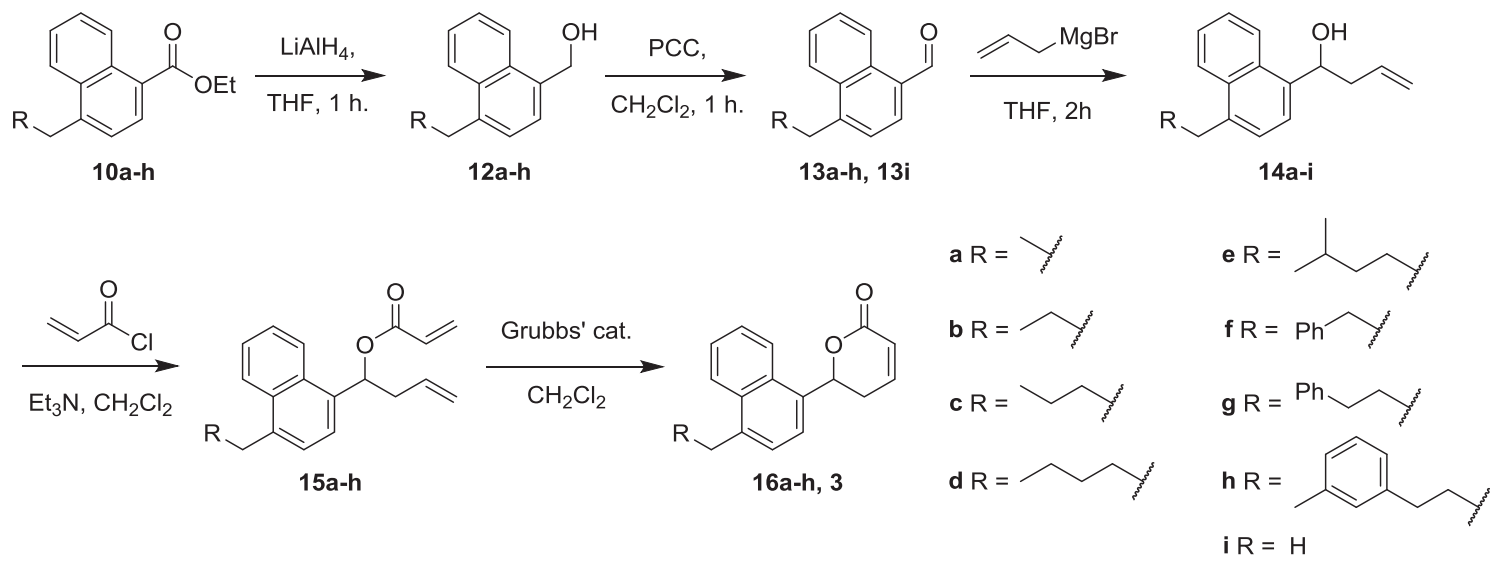

Scheme 2. Transformation of ethyl 4-alkyl-1-naphthoate derivatives (10a-h) to 4'-alkyl substituted klavuzon derivatives (16a-h).

$\underbrace{1}_{1}$

17

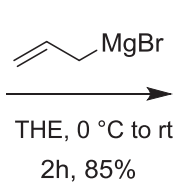

$2 \mathrm{~h}, 85 \%$<smiles>C=CCC(O)c1cc2c(c3ccccc13)CCCC2</smiles>

18

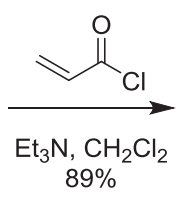

$89 \%$<smiles>C=CCC(OC(=O)C=C)c1cc2c(c3ccccc13)CCCC2</smiles>

19<smiles>O=C1C=CCC(c2cc3c(c4ccccc24)CCCC3)O1</smiles>

20
Scheme 3. Synthesis of 6-(1,2,3,4-tetrahydrophenanthren-9-yl)-5,6-dihydro-2Hpyran-2-one (20).

MTT results show that, both pancreatic cell lines were quite sensitive to camptothecin (CPT), a well known topoisomerase I poison. Interestingly, CPT does not show any selectivity over cancer cell lines probably due to the duplication times for cancerous (MIA PaCa-2) and immortalized healthy (HPDEC) cell lines were quite close to each other ( 40 and $34 \mathrm{~h}$, respectively). As it can be seen in Table 1 compound $\mathbf{2 0}$ showed five and two times stronger<smiles>[R]Cc1ccc(C(O)C=C)c2ccccc12</smiles>

Scheme 4. Synthesis of 4-alkylnaphthalen-1-yl substituted 3,6-dihydro-2H-pyran2-one derivatives (23a-e). 


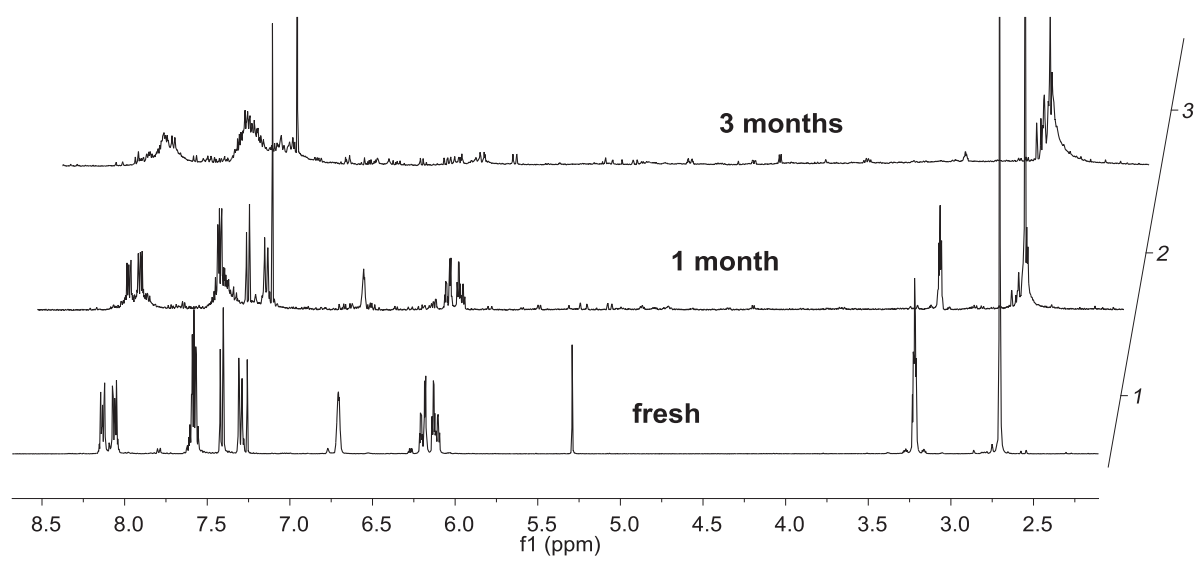

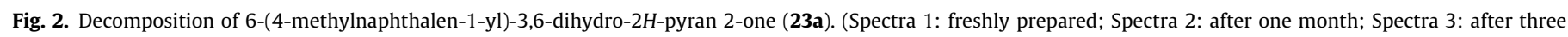
months).

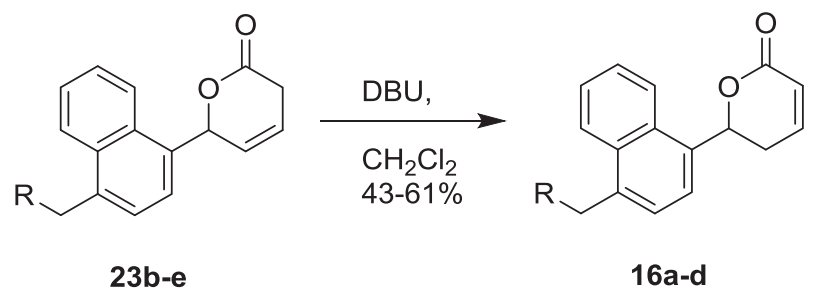

Fig. 3. Isomerization of 6-(4-alkylnaphthalen-1-yl)-3,6-dihydro-2H-pyran 2-one derivatives.

cytotoxic activity compared to compound 3 in MIA PaCa-2 and HPDEC cell lines, respectively. Level of cytotoxic activity of $4^{\prime}-$ ethylklavuzon (16a) was stronger compared to 4 '-methylklavuzon (3) in both cell lines, but selectivity was getting worse. In general, presence of a linear alkyl chain at position 4'- of klavuzon ( 3 and 16a-d) caused slightly selective cytotoxic activity for healthy pancreatic cell line (HPDEC). The length of the alkyl chain negatively affected potency of these compounds and shorter alkyl chains resulted more cytotoxic klavuzon derivatives. On the other hand, presence of a more bulky group at 4 '- position gave klavuzon derivatives (16e-h) that have comparable potency with $4^{\prime}$-propyl and 4'-butyl substituted klavuzons (16b and 16c). Nevertheless, selectivity index enhanced to 0.91-1.31 interval (Table 1).

Induction of apoptosis and cell cycle analysis of MIA PaCa-2 cells treated with varying concentrations of 4 '-methylklavuzon (3) were also studied by using Annexin V-FITC apoptosis detection kit (Fig. 4). At the end of $24 \mathrm{~h}$ of incubation with compound 3 the percentage of the early apoptotic MIA PaCa-2 cells slightly increased by concentration dependent manner. A similar statistically significant amount of increase was observed for the percentage of the late apoptotic cells, while the percentage of the necrotic cells did not change.

Besides, cell cycle analysis gave the clues about the existence of more than one action of mechanism for 4'-methylklavuzon (3). Incubation with low dose $(1 \mu \mathrm{M})$ of compound 3 resulted a small increase at G1 phase while that causes a similar amount of decrease at $S$ phase. The number of cells at G1 phase decreased significantly in MIA PaCa- 2 cell line incubated with 5 and $10 \mu \mathrm{M}$ of $4^{\prime}-$ methylklavuzon for $24 \mathrm{~h}$. Contrarily, number of cells at G2 phase increased significantly at the same concentrations. There is a small rise in the number of cells at $S$ phase in the presence of $10 \mu \mathrm{M}$ of $4^{\prime}-$ methylklavuzon but this increment was not significant (Fig. 4). Cell cycle arrest at $S$ phase may be the indication of Topo I inhibitory property of 4 '-methylklavuzon (3) and it is required high doses of compound 3. In addition, cell cycle arrest at G2 phase could mean that a number of cells complete the DNA duplication and another mechanism blocks the cell division at this stage.

According to apoptosis and cell cycle analysis, compound $\mathbf{3}$ causes apoptosis or cell cycle arrest only in a small fraction of cell population even at $10 \mu \mathrm{M}$ concentration at the end of $24 \mathrm{~h}$ incubation period. However, IC $\mathrm{I}_{50}$ value of compound $\mathbf{3}$ in MIA PaCa-2 cells was calculated as $0.96 \mu \mathrm{M}$ for $48 \mathrm{~h}$ treatment. There should be a sign for this cytotoxic effect at $24 \mathrm{~h}$ incubation. To control DNA integrity comet assay was performed for MIA PaCa-2 cells treated

Table 1

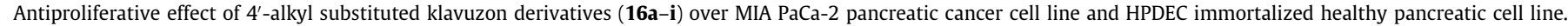

\begin{tabular}{|c|c|c|c|c|}
\hline \multirow[t]{3}{*}{ Comp. } & \multicolumn{3}{|l|}{$\mathrm{IC}_{50}($ in $\mu \mathrm{M})$} & \multirow[t]{3}{*}{ SI } \\
\hline & \multicolumn{2}{|l|}{ MIA PaCa-2 } & \multirow[t]{2}{*}{ HPDEC } & \\
\hline & Collagen & No collagen & & \\
\hline $\mathrm{CPT}$ & $0.18 \pm 0.01$ & & $0.21 \pm 0.01$ & 1.17 \\
\hline 3 & $0.96 \pm 0.17$ & $1.23 \pm 0.34$ & $0.34 \pm 0.09$ & 0.35 \\
\hline $16 a$ & $0.83 \pm 0.12$ & & $0.19 \pm 0.05$ & 0.23 \\
\hline $16 b$ & $1.50 \pm 0.61$ & $2.62 \pm 1.09$ & $0.47 \pm 0.15$ & 0.31 \\
\hline $16 c$ & $6.30 \pm 0.73$ & $7.37 \pm 1.21$ & $0.49 \pm 0.17$ & 0.08 \\
\hline $16 \mathrm{~d}$ & $6.70 \pm 0.20$ & & $2.83 \pm 0.38$ & 0.42 \\
\hline $16 \mathrm{e}$ & $4.09 \pm 0.20$ & & $4.50 \pm 0.48$ & 1.10 \\
\hline $16 f$ & $2.20 \pm 0.11$ & & $2.88 \pm 0.49$ & 1.31 \\
\hline $16 g$ & $3.21 \pm 0.39$ & & $3.97 \pm 0.50$ & 1.24 \\
\hline $16 \mathrm{~h}$ & $1.40 \pm 0.69$ & & $1.28 \pm 0.11$ & 0.91 \\
\hline 20 & $0.16 \pm 0.03$ & & $0.15 \pm 0.04$ & 0.94 \\
\hline
\end{tabular}

SI: Selectivity Index $=\mathrm{IC}_{50}$ in $\mathrm{HPDEC} / \mathrm{IC}_{50}$ in MIA PaCa-2, where $\mathrm{IC}_{50}$ is the concentration required to decrease the cell population $50 \%$. CPT: camptothecin. 

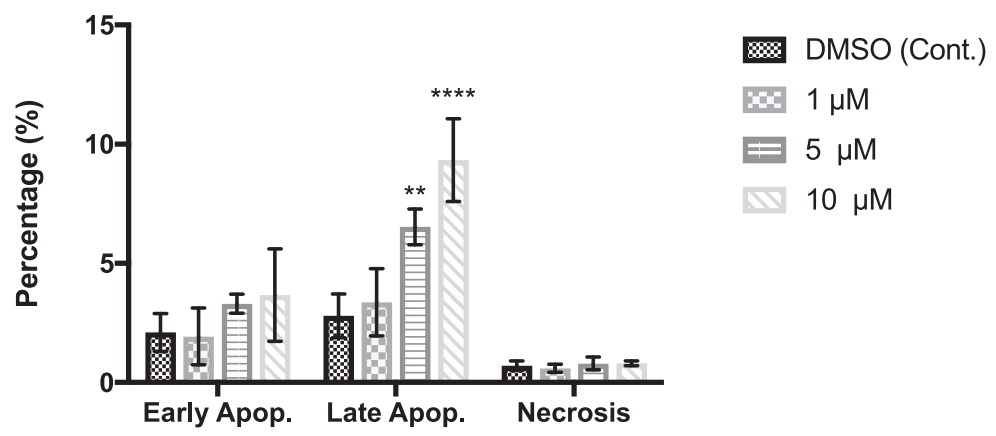

According to Two-way ANOVA Bonferroni's multiple comparisons test P Value for; ** is smaller than $0.01(\mathrm{P}<0.01)$ and for $* * * *$ is smaller than $0.0001(\mathrm{P}<0.0001)$

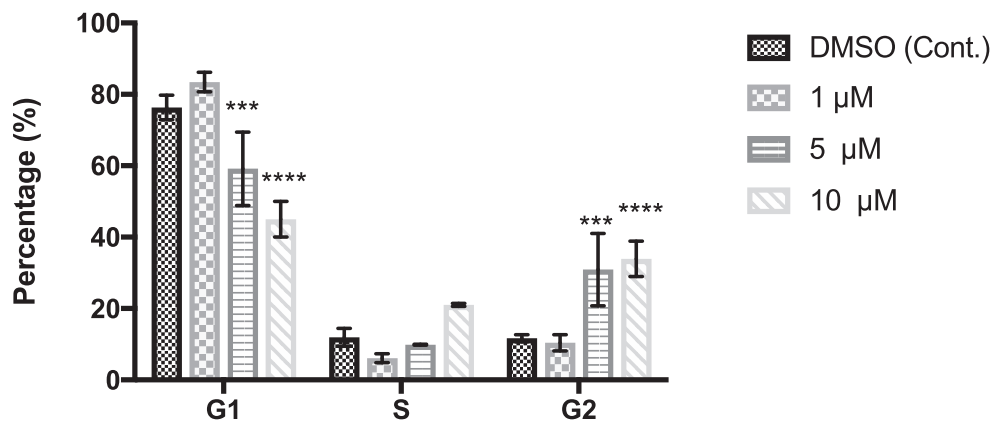

Two-way ANOVA Bonferroni's multiple comparisons test: *** P Values are equal to 0.0008 for G1 and 0.0002 for $\mathrm{G} 2$; **** $\mathrm{P}$ Value is smaller than $0.0001(\mathrm{P}<0.0001)$

Fig. 4. Concentration dependent apoptosis and cell cycle analysis for $4^{\prime}$-methylklavuzon (3) treated MIA PaCa-2 cells.

with varying concentrations of compound 3 (Fig. 5). An alkaline lysis solution was used to detect the possible double and single strand DNA breaks. ${ }^{24}$ Hydrogen peroxide was used as positive control. Formation of DNA breaks could easily be seen for $53 \%$ MIA PaCa- 2 cells treated with $5 \mu \mathrm{M}$ of $4^{\prime}$-methylklavuzon (3), although total number of the apoptotic cells was around $14 \%$ of the total cell population. A similar inconsistency was also found for MIA PaCa-2 cells treated with $10 \mu \mathrm{M}$ of compound 3 . While only $20 \%$ of the cells were apoptotic at this concentration, $42 \%$ of the cell population gave comet as an indication of DNA breaks. Mismatch between the percentages of cells at apoptosis and percentages of cells giving comet can be explained by Topo I inhibition property of klavuzons. Topoisomerases, including topoisomerase I, play crucial role in the cellular response to DNA damage, DNA repair and apoptosis. ${ }^{25}$ Any

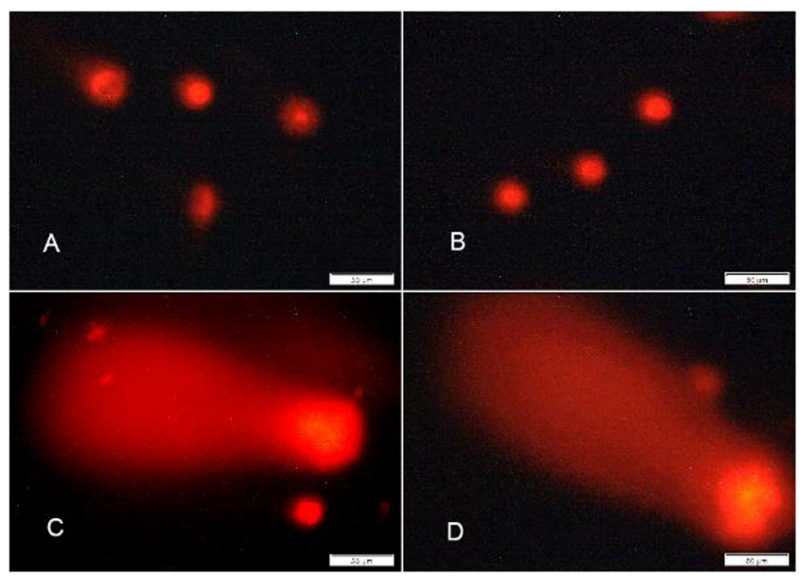

Fig. 5. Comet assay for MIA PaCa-2 cells treated with 4'-methylklavuzon (3). damage in DNA cannot be repaired when all Topo I enzymes are inhibited by compound 3.

Nucleocytoplasmic transport systems play a critical role in intracellular localization and regulation of proteins in each cell. This balance is quite important and is typically uncontrolled in cancer cells. Specific localization of tumor suppressor and oncoproteins is quite important because any abnormal localization of these proteins can cause inactivation or over-activation. Hence it was believed that inhibitors of nucleocytoplasmic transport systems could be an anticancer agent for a long time. ${ }^{26}$ In this respect, concentration dependent CRM1 inhibitory properties of klavuzons 3 , 16b, 16c, 16d and 20 were studied by visualization of CRM1 mediated nuclear export of Riok2 (Serine/threonine-protein kinase Rio2) in HeLa cells. CRM1 inhibitory property of goniothalamin was shown previously and it was used as positive control. ${ }^{17}$ DAPI was used to stain the nucleus of the cells for comparison purpose. For each molecule, number of cells in three separate pictures were counted and percent inhibition were calculated by dividing the number of CRM1 inhibited cells to the number of total cells.

According to the results, goniothalamin started to inhibit CRM1 (50\%) at $1.0 \mu \mathrm{M}$ concentration at the end of the 90 min of incubation and CRM1 was inhibited completely in $100 \%$ of the cell population at $5 \mu \mathrm{M}$ concentration. A longer incubation period $(6 \mathrm{~h})$ gave similar trend and at $5 \mu \mathrm{M}$ concentration, goniothalamin completely inhibited the nucleocytoplasmic transport system in all cells (Fig. 6). On the other hand, compound 3 started to inhibit CRM1 at $0.2 \mu \mathrm{M}$ concentration even at the end of the 90 min of incubation (87\%). A similar CRM1 inhibition potency was also found for compounds $\mathbf{1 6 b}$ and 16c. Additionally, compound 16d could not inhibit CRM1 at $0.2 \mu \mathrm{M}$ concentration. However, it inhibited CRM1 completely at $1.0 \mu \mathrm{M}$ concentration at the end of $6 \mathrm{~h}$ of incubation. Interestingly, compounds $\mathbf{1 6 c}$ and $\mathbf{1 6 d}$ had quite simi- 


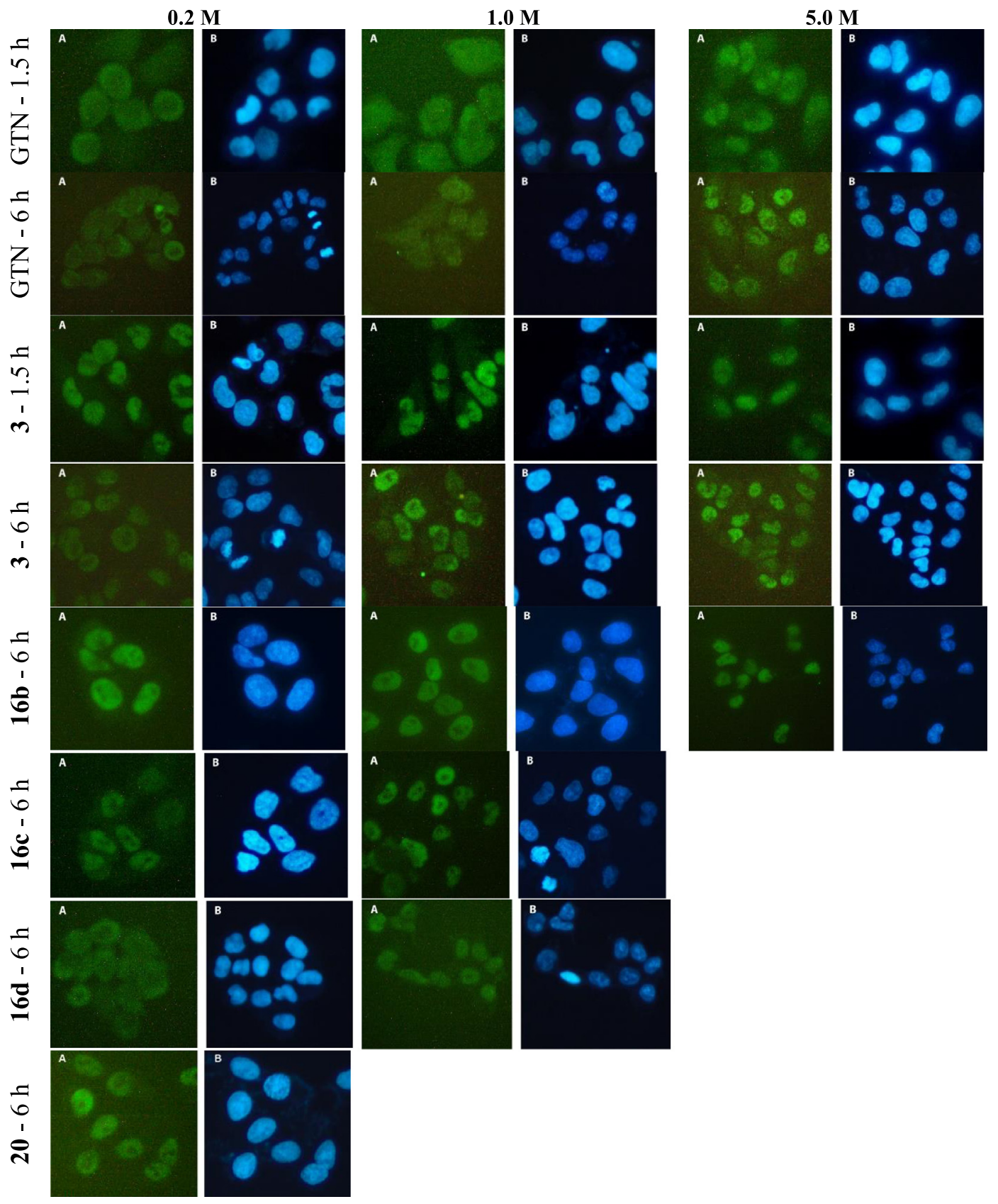

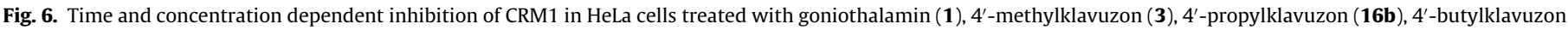
(16c), 4'-pentylklavuzon (16d) derivatives and compound 20.

lar IC 50 values in MIA PaCa-2 cells (6.30 and $6.70 \mu \mathrm{M}$, respectively) and it is quite difficult to correlate their CRM1 inhibitory potency with these $\mathrm{IC}_{50}$ values. Lastly compound $\mathbf{2 0}$ showed strong CRM1 inhibition activity at $0.2 \mu \mathrm{M}$ concentration at the end of $6 \mathrm{~h}$ of incubation (Fig. 6). Since compounds $\mathbf{3}$ and $\mathbf{2 0}$ were the most cytotoxic klavuzon derivatives, their CRM1 inhibitory properties were also tested at lower doses (Fig. SM1, Supplementary materials). It was found that both compounds started to inhibit CRM1 at 20 nM concentrations, and they almost inhibited CRM1 completely in all cells at $50 \mathrm{nM}$ concentrations.

Lastly, antiproliferative activity of compound $\mathbf{2 0}$ was tested over 3D spheroids generated from HuH-7 hepatocellular cancer cell line in 96 well hanging drop plates in $48 \mathrm{~h}$. Then varying concentrations of compound $\mathbf{2 0}$ were applied to the spheroids. Goniothalamin was also applied in a single dose just for comparison purpose (Fig. 7). Spheroids were monitored by microscope at the end of 24,48 , and $72 \mathrm{~h}$ of incubation by using $4 \mathrm{X}$ objective, then the same spheroids were treated with propidium iodide (PI) staining and monitored by fluorescence microscope by using $4 \mathrm{X}$ objective to visualize the dead cells. As it can be seen in Fig. 7, $50 \mu \mathrm{M}$ concentration of goniothalamin caused significant cell death just after $24 \mathrm{~h}$ of incubation compared to untreated or DMSO control HuH-7 spheroids. Although its cytotoxic activity did not increase in $48 \mathrm{~h}$ of incubation, the size of the spheroid was smaller than the sizes of the untreated or DMSO control spheroids. At the end of the $72 \mathrm{~h}$ of incubation, all of the cells in goniothalamin treated spheroids were dead.

On the other hand, compound $\mathbf{2 0}$ inhibited the growth of 3D spheroids almost in all tested concentrations and it caused significant cell death at 10 and $30 \mu \mathrm{M}$ concentrations in $48 \mathrm{~h}$. Spheroid 


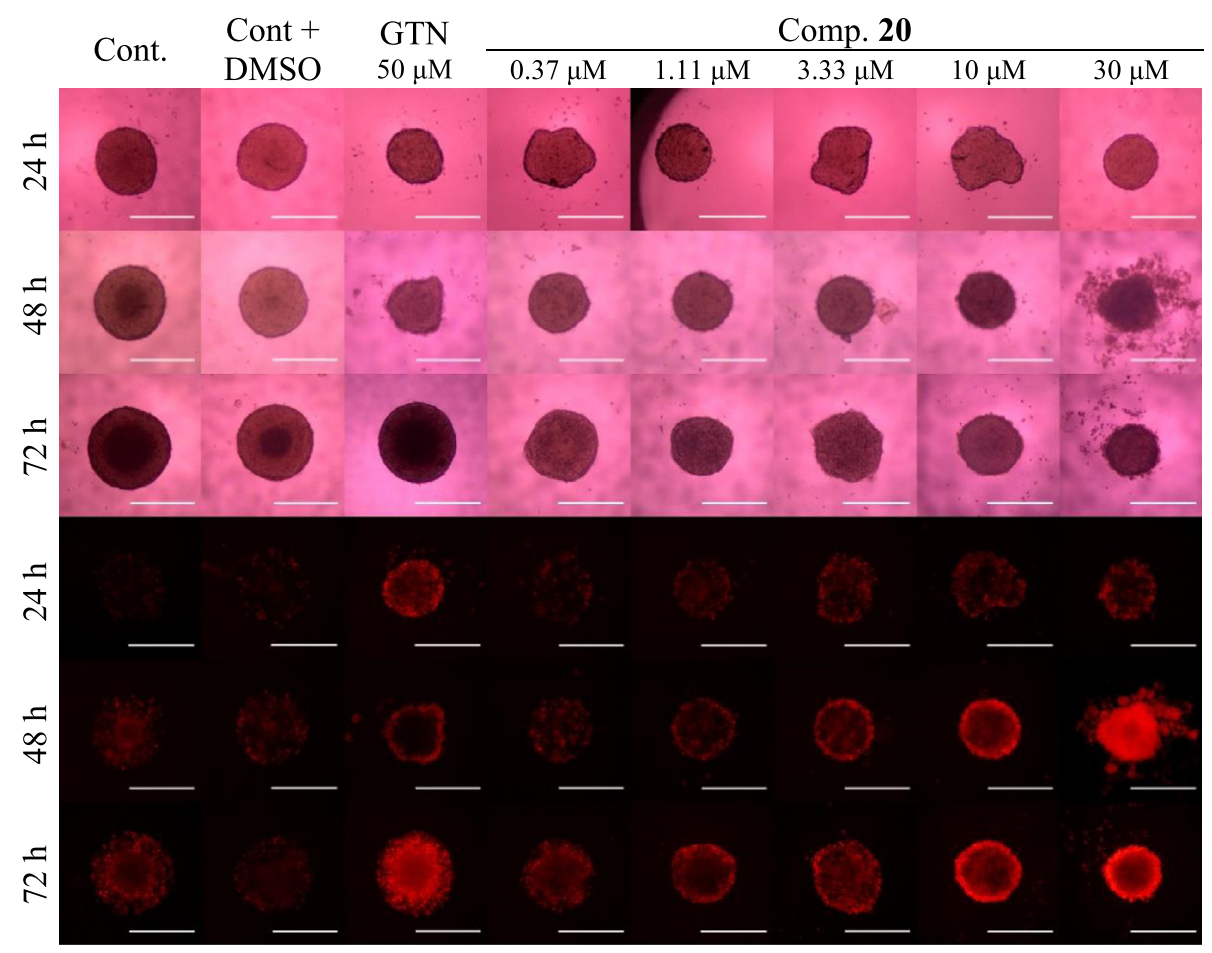

Fig. 7. Time and concentration dependent cytotoxic activity of compound $\mathbf{2 0}$ in $3 \mathrm{D}$ spheroids of HuH-7 cells. Scale bars $=0.5 \mathrm{~mm}$.

even started to become disintegrated at $30 \mu \mathrm{M}$ concentration. Similar dose dependent response was observed at the end of $72 \mathrm{~h}$ of incubation with compound $\mathbf{2 0}$.

\section{Conclusion}

Synthesis of novel 4'-alkyl substituted klavuzon derivatives were successfully completed in eight steps starting from 4methyl-1-naphthoic acid. MTT cell viability assay over cancerous (MIA PaCa-2) and immortalized healthy (HPDEC) pancreatic cell lines revealed that compound $\mathbf{2 0}$ has a remarkable cytotoxic effect in both cell lines without having any selectivity. Two other novel klavuzon derivatives, 4'-methylklavuzon (3) and 4'-ethylklavuzon (12a), are quite cytotoxic and selective to HPDEC cell line with $\mathrm{IC}_{50}$ values at nanomolar concentrations. Among these, 4'methylklavuzon (3) and compound $\mathbf{2 0}$ were chosen for further biological activity studies and it is found that $4^{\prime}$-methylklavuzon (3) induces apoptosis in MIA PaCa-2 cells at 5 and $10 \mu \mathrm{M}$ concentrations. Comet assay also indicates the formation of single and double strand DNA breaks in MIA PaCa-2 cells treated with 4'methylklavuzon (3) for $24 \mathrm{~h}$. Cell cycle analysis of MIA PaCa-2 cells treated with varying concentrations of compound 3 surprisingly implies the presence of more than one action of mechanism for this compound. At $1 \mu \mathrm{M}$ concentration, compound $\mathbf{3}$ causes an arrest at G1 phase while at higher concentrations that results in G2 arrest.

Beside the previously reported Topo I inhibition, time and concentration dependent CRM1 inhibitory properties of klavuzon derivatives have been shown as a second mechanism of action in this work. Especially, compounds $\mathbf{3}$ and $\mathbf{2 0}$ are the most effective derivatives and they completely inhibit CRM1 activity at $50 \mathrm{nM}$ concentrations in $6 \mathrm{~h}$ of incubation.

Compared to traditional two-dimensional cell cultures, 3D cell cultures are considered as a much better way to represent in vivo environment. Hence, the most active derivative, compound 20, has been tested in HuH-7 derived 3D spheroids and it has been found that compound $\mathbf{2 0}$ inhibited the growth of 3D spheroids and it caused significant cell death at 10 and $30 \mu \mathrm{M}$ concentrations in $48 \mathrm{~h}$. Therefore, compound 20 can be a good lead compound for further studies.

\section{Author contributions}

All authors have approved the final version of the manuscript.

\section{Acknowledgements}

This work was supported by the Scientific and Technological Research Council of Turkey (TÜBITAK, 113Z146). The authors would like to acknowledge networking support by the COST Action BM1204. We also would like to thank Mehmet S. Yildız due to his help in MTT assays. We thank to Biotechnology and Bioengineering Research Central Research Laboratories at Izmir Institute of Technology for their help in bioactivity studies.

\section{A. Supplementary data}

Supplementary data associated with this article can be found, in the online version, at http://dx.doi.org/10.1016/j.bmc.2017.06.030.

\section{References}

1. Siegel RL, Miller KD, Jemal A. Cancer statistics, 2017. CA Cancer J Clin. 2017;67:7-30

2. Mah R, Thomas JR, Shafer CM. Drug discovery considerations in the development of covalent inhibitors. Bioorg Med Chem Lett. 2014;24:33-39.

3. Enders D, Steinbusch D. An efficient asymmetric synthesis of tarchonanthuslactone. Eur J Org Chem. 2003;2003:4450-4454.

4. Hlubucek J, Robertson A. (+)-(5S)- $\delta$-Lactone of 5-hydroxy-7-phenylhepta-2,6dienoic acid, a natural product from Cryptocarya caloneura (Scheff.) Kostermans. Aust J Chem. 1967;20:2199-2206.

5. Al-Qubaisi M, Rozita R, Yeap SK, Omar AR, Ali AM, Alitheen NB. Selective cytotoxicity of goniothalamin against hepatoblastoma HepG2 Cells. Molecules. 2011;16:2944-2959.

6. Chatchai W, Boonsong W, Puttachat S, Arunporn I, Niwat K. Goniothalamin, a cytotoxic compound, isolated from Goniothalamus macrophyllus (Blume) 
Hook. f. \& Thomson var. macrophyllus. Songklanakarin. J Sci Technol. 2005;27:479-487.

7. de Fatima A, Kohn LK, Antonio MA, de Carvalho JE, Pilli RA. (R)-goniothalamin: total syntheses and cytotoxic activity against cancer cell lines. Bioorgan Med Chem. 2005;13:2927-2933.

8. de Fatima A, Kohn LK, de Carvalho JE, Pilli RA. Cytotoxic activity of (S)goniothalamin and analogues against human cancer cells. Bioorgan Med Chem. 2006;14:622-631.

9. de Fatima A, Pilli RA. Total syntheses of (R)-argentilactone and (R)goniothalamin via catalytic enantioselective allylation of aldehydes. Tetrahedron Lett. 2003;44:8721-8724.

10. Barcelos RC, Pastre JC, Caixeta V, Vendramini-Costa DB, de Carvalho JE, Pilli RA Synthesis of methoxylated goniothalamin, aza-goniothalamin and gammapyrones and their in vitro evaluation against human cancer cells. Bioorgan Med Chem. 2012;20:3635-3651.

11. Bennett F, Knight DW. An alternative approach to mevinic acid analogues from methyl (3R)-3-hydroxy-5-hexenoate and an extension to rational syntheses of $(+)-(6 R)$-goniothalamin and its non-natural (-)-(6S)-enantiomer. Tetrahedron Lett. 1988;29:4625-4628.

12. Bluet G, Bazan-Tejeda B, Campagne JM. Catalytic asymmetric access to alpha, beta unsaturated delta-lactones through a vinylogous aldol reaction: Application to the total synthesis of the Prelog-Djerassi lactone. Org Lett. 2001;3:3807-3810.

13. Gruttadauria M, Lo Meo P, Noto R. Short and efficient chemoenzymatic synthesis of goniothalamin. Tetrahedron Lett. 2004;45:83-85.

14. Harsh P, O'Doherty GA. De, Novo asymmetric syntheses of (+)-goniothalamin, (+)-goniothalamin oxide, and 7,8-bis-epi-goniothalamin using asymmetric allylations. Tetrahedron. 2009;65:5051-5055.

15. Honda T, Kametani T, Kanai K, Tatsuzaki Y, Tsubuki M. Enantioselective syntheses of (+)-acetylphomalactone and (6R)-(+)-goniothalamin from 2 furylmethanols. J Chem Soc, Perkin Trans 1. 1990(6);1733-1737.
16. Zhou FS, Tang WD, Mu Q, et al. Semisynthesis and antitumor activities of new styryl-lactone derivatives. Chem Pharm Bull. 2005;53:1387-1391.

17. Wach J-Y, Güttinger S, Kutay U, Gademann K. The cytotoxic styryl lactone goniothalamin is an inhibitor of nucleocytoplasmic transport. Bioorg Med Chem Lett. 2010;20:2843-2846.

18. Akçok I, Mete D, Şen A, Kasaplar P, Korkmaz KS, Çağır A. Synthesis and Topoisomerase I inhibitory properties of klavuzon derivatives. Bioorg Chem. 2017;71:275-284.

19. de Fatima A, Zambuzzi WF, Modolo LV, et al. Cytotoxicity of goniothalamin enantiomers in renal cancer cells: Involvement of nitric oxide, apoptosis and autophagy. Chem-Biol Interact. 2008;176:143-150.

20. Vendramini-Costa DB, de Castro IBD, Ruiz A, Marquissolo C, Pilli RA, de Carvalho JE. Effect of goniothalamin on the development of Ehrlich solid tumor in mice. Bioorgan Med Chem. 2010;18:6742-6747.

21. Kasaplar P, Yilmazer O, Cagir A. 6-Bicycloaryl substituted (S)- and (R)-5,6dihydro-2H-pyran-2-ones: asymmetric synthesis, and anti-proliferative properties. Bioorgan Med Chem. 2009;17:311-318.

22. Talevi A. Multi-target pharmacology: possibilities and limitations of the "skeleton key approach" from a medicinal chemist perspective. Front Pharmacol. 2015;6:205.

23. Node M, Kumar K, Nishide K, Ohsugi S-I, Miyamoto T. Odorless substitutes for foul-smelling thiols: syntheses and applications. Tetrahedron Lett. 2001;42:9207-9210.

24. Liao W, McNutt MA, Zhu W-G. The comet assay: a sensitive method for detecting DNA damage in individual cells. Methods. 2009;48:46-53.

25. Søe K, Rockstroh A, Grosse F. Role of Human Topoisomerase I in DNA Repair and Apoptosis. In: Lankenau D-H, ed. Genome Integrity. Berlin Heidelberg: Springer, Berlin Heidelberg; 2007:343-362.

26. Hill R, Cautain B, de Pedro N, Link W. Targeting nucleocytoplasmic transport in cancer therapy. Oncotarget. 2013;5(1). 